1 Dulletin d'analyse phénoménologique XII 1, 2016

ISSN 1782-2041 http://popups.ulg.ac.be/1782-2041/

\title{
Heidegger's Anxiety: On the Role of Mood in Phenomenological Method
}

By R. MATTHEW SHOCKEY

Indiana University - South Bend

\begin{abstract}
Heidegger's early project aims to articulate the form of our being as Dasein, and he says that for this usually hidden form to become accessible, a certain kind of "mood" is required of the philosopher. This "ground-mood" he identifies in Sein und Zeit as anxiety. He also, however, presents anxiety as a mood anyone, philosopher or not, experiences when there is some significant breakdown in the living of her life. I argue here that there are largely unrecognized problems with this conflation of methodological and "existential" moods, but that there is nevertheless a compelling methodological account of anxiety that can be teased apart from the existentialist one: methodologically understood, anxiety is a self-affected state of the ontologist, one that results from her asking ontological questions of herself, and, by imagining crisis or breakdown, withdrawing from her determinate situation to a position where she can see the form of her own activity as questioner and imaginer. I draw out some consequences this has for how we should understand the place of ontological understanding in living one's life, and I conclude by briefly showing how my reading helps us see Heidegger as developing key elements in the work of Descartes and Kant.
\end{abstract}

\section{§1. Introduction}

In Sein und Zeit, ${ }^{1}$ Martin Heidegger presents an account of us as "Dasein:" world-embedded, socially-situated, self-interpreting agents, defin-

1 Martin Heidegger, Sein und Zeit, 17th ed. (Tubingen: Max Niemeyer, 1993 [1927]); English translation: Being and Time, trans. John Macquarrie and Edward 
ed by the fact that we understand entities as being. ${ }^{1}$ To understand an entity as being is, according to Heidegger, to relate to or comport towards it in terms of its being, which means in terms of an a priori form or structure that determines its kind or way of being (presence-at-hand [Vorhandenheit], readiness-to-hand [Zuhandenheit], care [Sorge], etc.). Our understanding of the forms or ways of being is, however, usually only "pre-ontological," ${ }^{2}$ i.e., merely tacit, not consciously conceptualized and philosophically "thematized." "So, while we take entities to be, we are typically not explicitly aware of the underlying basis or ground that enables us to do so. We are, Heidegger says, appropriating a key Platonic and subsequently Christian notion, always "fallen" away from being and into things, but nevertheless dependent on being in all our dealings with them. Nevertheless, Heidegger (like the Platonists) thinks that it is possible for us to bring what is usually hidden to light, to allow being itself rather than entities to be a phenomenon for us. This is precisely what he seeks to do in $S \& Z$, and in such a way as to ultimately uncover the "sense [Sinn]" unifies the multiple ways of being we grasp.

Robinson (San Francisco: Harper \& Row, 1962). Henceforth cited as $S \& Z$ with references to the German pagination only. I adhere as closely as possible to the translation of Macquarrie and Robinson (M\&R) but occasionally modify it without notice.

${ }^{1}$ I use "entity" and "entities" to translate "Seiendes" and "Seienden" in order to avoid confusion over the term "being," which I use to translate Sein. I've also kept M\&R's terms "readiness-to-hand" and "presence-at-hand" as the translations of "Zuhandenheit" and "Vorhandenheit." These still seem to me as good as any, and when writing for an audience who can be expected to be familiar with the German, as in an academic article such as this one, it shouldn't matter much which translations one uses.

${ }^{2}$ E.g. $S \& Z 12,16$. The latter puts the point thus: Dasein's "being-constitution [Seinsverfassung] (...underst[ood] in the sense of Dasein's 'categorial structure') remains concealed from it."

${ }^{3}$ While perhaps not entirely consistent in his use of this term, in the majority of cases — beginning at $S \& Z 2$ - Heidegger uses it (and, relatedly, the Latinate terms for interpretation [Interpretation] and explicit [Explizit]) to refer to the specific kind of articulation of being that is performed in doing ontology. Thus, while Brandom is right to say that for Heidegger Dasein is "the Being who Thematizes," he is wrong to count ontical asserting as thematizing. See Robert B. Brandom, "Dasein, the Being That Thematizes," in Tales of the Mighty Dead (Cambridge, MA: Harvard University Press, 2004), 234-47.

${ }^{4}$ Heidegger defines sense as "that wherein the intelligibility [Verstehbarkeit] of something maintains itself" ( $S \& Z 324)$. In the case of being, this refers to that which 
But how exactly can being become a phenomenon for us, given that it ordinarily lies hidden? What, in other words, makes ontology, the discursive articulation of being and its sense, possible? This question - which, in various permutations, obsessed Heidegger throughout his career - is approached in $S \& Z$ through the seemingly narrower question of how our own way of being is available for discursive articulation. As Dasein, our being is necessarily "at issue" for us, ${ }^{1}$ and it is "in each case mine [je meines]," thus at issue for each of us as singular individuals. This means that discursively articulating the being of Dasein requires each of us who does so to articulate our own form, that of first-person singularity as such. Yet our being is, like all being, in some fundamental way hidden from view. And so the question of how being becomes available or "disclosed [erschlossen]" to me in such a way that I may bring it to conceptual articulation is, in the first instance, the question: how do I relate to myself in such a way that I may see and articulate not what makes me the particular 'me' I am, but rather my own ontological form as an instance of Dasein? ${ }^{2}$ The goal of the analytic of Dasein is thus, Heidegger says, appropriating one of the dominant metaphors of modern thought, to "make an entity - the inquirer - transparent [durchsichtig] in his own being." 3 His analysis of Dasein may thus be profitably read as he explicitly indicates it should, as a working out of the meaning of

allows us to understand different ways of being as all ways of being. In $S \& Z$ Heidegger sought this unitary ground in time. I don't address time here, but the basic methodological picture I draw is meant ultimately to make sense of how time as the ground of being may come into view.

${ }^{1} S \& Z$ 12; cp., e.g., $S \& Z 42,133,143$. I argue in "Heidegger on Understanding One's Own Being" (New Yearbook for Phenomenology and Phenomenological Philosophy XI (2012): 128-43) that when Heidegger says this of us, he means that our being, care, understood as our constitutive ontological — 'categorial' — structure or form, is at issue for us, much as our being as rational is at issue for us in Kant's philosophy. Most readings, by contrast, treat the "being" that is at issue as something particular to the individual liver of a life or to their particular social world. I challenge this in sect. 2 below.

${ }^{2}$ Elsewhere he reinforces this general orientation: "returning to the subject, in the broadest possible sense, is the only path that is correct" (Grundprobleme der Phänomenologie, GA 24, [Frankfurt am Main: Vittorio Klostermann, 1975 (1927)], 103; English translation: The Basic Problems of Phenomenology, trans. Albert Hofstadter [Bloomington: Indiana University Press, 1988]; hereafter cited as GP with page references to the German). Here Heidegger sees this not as a novel Cartesian move, but as going in one way or another back to Plato and Aristotle.

${ }^{3} S \& Z 7$. 
the "sum," to which Descartes drew our attention but failed adequately to analyze."

Now, Heidegger's answer to the question of how I take up myself so that I may achieve this formal self-analysis is rather complicated (and not as clearly articulated as it might be). It involves seeing how each of the aspects of the structure of "being-in [In-sein]" (Befindlichkeit, ${ }^{2}$ discourse [Rede], and understanding [Verstehen]) manifest themselves in ontological activity, that is, the activity of the one who deliberately engages in philosophical questioning of being. Here I want to focus on the most striking part of this: Heidegger's claim that in order to see my being, i.e., my ontological form, I must be in a distinctive sort of mood (Stimmung), what he calls a "groundmood [Grundstimmung]." 3 Such moods are concrete determinations of Befindlichkeit, and so they have associated modes of discourse and understanding, but moods receive more attention than these other modes, evidence that Heidegger thinks that the question of phenomenological

\footnotetext{
${ }^{1} S \& Z$ 46. For further exploration of the Cartesian roots of Heidegger's thought, see my "Heidegger's Descartes and Heidegger's Cartesianism," European Journal of Philosophy 20:2 (2010): 285-311. An exceptionally thorough and stimulating examination of Heidegger's career-long engagement with Descartes may also be found in Christophe Perrin, Entendre la métaphysique: Les significations de la pensée de Descartes dans l'ouvre de Heidegger (Louvain and Paris: Éditions Peeters, 2013), my review of which is forthcoming in the Revue philosophique de Louvain.

${ }^{2}$ I've here decided to leave "Befindlichkeit" untranslated. Macquarrie and Robinson's "state-of-mind" is, to my mind, adequate if heard in a colloquial sense, but enough people have criticized it that I won't insist. I've previously tried "selffinding," which picks up nicely on the underlying German idiom and captures nicely the relevant philosophical idea, but nearly every reader of earlier drafts of this paper found it problematic, so I dropped it. It's also now not uncommon to rely on the idea of disposition to try to render Befindlichkeit into English, but this eliminates or at least hides the important connotations of the passivity and receptivity of being affected (as in passion, emotion, and mood), and they hide the fact that in such affectivity one finds oneself in a certain way.

3 "Stimmung" refers also to the tuning of a musical instrument and so connotes a sense of being attuned to... I will freely play off this sense as I go, but I'll stick with "mood" as a direct translation of the term. Also, as we will see, Heidegger also sometimes uses the terms "Befindlichkeit" and "Grundbefindlichkeit" to refer to mood. I can't argue in detail the textual points here, but, in my view, if he were consistent, moods would always be seen as determinate instantiations of the general category ("existentiale") of Befindlichkeit, which has its proper place in the formal triad of being-in (In-sein) along with Verstehen and Rede.
} 
method is somehow centered around the nature of affectivity. This is, at first glance, more than a little strange, both because the variability and unpredictability of moods seems at odds with the universality of what is understood when doing ontology (the structure of Dasein is the same for each of us), and also (and perhaps relatedly) because the ground of the intelligibility of things is usually assumed to be revealed not through affect, but rather in conceptual cognition, which we would normally associate with discourse and understanding. Nevertheless, the idea that we must be in the right sort of mood in order to 'see' being is a natural consequence of Heidegger's view that to understand anything at all involves an ongoing affective attunement to what we understand, and to ourselves as understanders. ${ }^{1}$ Our moods are what manifest this most basically: they reflect our general feeling of the world as a whole as either conducive or resistant to the actions we undertake in it, which in turn shapes our orientation to particular entities we encounter. Since this affective attunement is essential to us, it doesn't go away just because we seek to shift our attention from entities to being. A ground-mood is, then, the idea of an affective state in which we are affected by, and so attuned to, being, in such a way that it is explicitly available for thematic, discursive treatment.

Or so I will argue. Unfortunately, Heidegger's discussion of groundmoods is equivocal. He tends to collapse - or at least invite the collapse of - the mood of the one doing ontology into the mood that one - anyone,

\footnotetext{
${ }^{1}$ This is not as novel an idea as it is sometimes made out to be, for it builds on and develops a view widely held in the tradition that, on the one hand, human cognition depends on "passion," i.e., being affected by that which is known in such a way that it engages one's volition, and that, on the other, when we act, in addition to whatever intended effect of our action we produce, we also affect ourselves in such a way that we feel ourselves acting. Descartes, for instance, develops such an idea in Les Passions de l'Ame (Part I, esp. §19), a work which teases out the consequences of his dualism for human embodiment and agency. There is a direct line (via Leibniz and others) from Descartes' account of self-perception in action to Kant's idea of selfaffection (in theoretical, practical, and aesthetic experience) that, as I will touch on in my conclusion, Heidegger came to find significant and (or, because) anticipatory of his own ideas. Thus, when he disparages the tradition for tending to reduce affects to merely subjective "accompanying phenomena" to volition and cognition ( $S \& Z 139)$, he's to some extent setting up a straw man. For a corrective to some of the common distortions of $17^{\text {th }}$ century thinkers including Descartes on this topic, see Susan James, Passion and Action: The Emotions in Seventeenth Century Philosophy (Oxford: Oxford University Press, 1997) and Michael Moriarty, Early Modern French Thought: The Age of Suspicion (Oxford: Oxford University Press, 2003).
} 
philosopher or not - experiences in extreme situations that reveal or call into question the overall sense of her life's coherence and meaning. Thus in $S \& Z$ the ground-mood that gets developed in detail, anxiety (Angst), ${ }^{1}$ does double-duty, on the one hand as the mood in which the formal beingstructures of Dasein are disclosed to the philosopher, and, on the other, as the mood of total crisis in or breakdown of one's life. I will argue, however, that the mood of the ontologist, the one who sees and thematically treats the formal structures of Dasein, cannot reasonably be understood to be a mood of extreme crisis or breakdown. It must instead be understood as a deliberately induced mood in which the concerns of one's life are put in abeyance through the act of asking distinctly ontological questions about oneself. Anxiety as the mood of crisis or breakdown is then a distinct mood from the 'anxiety' of the philosopher, though it is a mood that it is perhaps necessary to reflect upon in order to do ontology.

I proceed as follows: In $\S 2$, I elaborate further the idea that when Heidegger talks about the being of entities, he is referring to universal and a priori forms or structures which ground our understanding of entities as entities. This will make clear exactly what is supposed to be disclosed in a ground-mood when understood methodologically as the mood of the ontologist. In $\S 3$, I argue that it's implausible to think that an experience of breakdown or crisis reveals one's being in the way required for thematizing it philosophically. In $\S 4$ I then sketch a reading of anxiety in $S \& Z$ that shows how it may be seen not (or not only) as the mood of crisis or breakdown, but rather as a distinctly philosophical mood that results from ontological selfquestioning (itself a discursively structured, projective activity of our understanding). In $\S 5$ I discuss the implications this has for understanding the relation between ontological self-understanding and lived existence. I conclude in $\S 6$ with some remarks that connect my reading of Heidegger to his treatment of Descartes and Kant, in order to show how it helps us see him as continuing to extend certain key threads of modern thought. ${ }^{2}$

\footnotetext{
${ }^{1}$ Boredom is the only other mood to get extensive analysis by Heidegger, in the Grundbegriffe der Metaphysik lectures (GA 29/30; The Fundamental Concepts of Metaphysics: World, Finitude, Solitude. Tr. William McNeill and Nicholas Walker [Indianapolis: Indiana University Press, 1995]; hereafter GM). While much of what I say here extends to it, I will say little about it directly. Heidegger also mentions more positive moods like joy as having the same sort of character, but he doesn't analyze them in any detail.

${ }^{2}$ I should acknowledge at the outset what is in any case already apparent, that my overall reading of Heidegger is, to some extent at least, what he would call a "violent" one (see the Preface to the Second Edition and p. 202 of Kant und das
} 


\section{§2. The A Priori Forms of Being}

Early in $S \& Z$ Heidegger claims that being is that "on the basis of which [woraufhin]" entities are intelligible as entities. ${ }^{1}$ Though what this means in the case of Dasein is ultimately what's most important here, I want first to consider its meaning in his account of the "world" of human existence and the things of use (Zeug) - tools, materials, etc. — which, along with other people, constitute this world. ${ }^{2}$ This will allow me to make some general points about his project that will help with my discussion of Dasein's being, and it will make clear where many readers go astray in reading $S \& Z$ in the chapters that precede his discussion of anxiety, in a way that detrimentally affects their interpretations of it.

Heidegger elucidates the being of those entities we deal with in our engagement in the world as readiness-to-hand (Zuhandenheit). These entities, things of use, are each determined by a particular set of reference-relations (Verweisungen): an "in-order-to [Um-zu]," a "towards-which [Wo-zu]," and a "for-the-sake-of-which [Worumwillen]." These reference relations define an entity's particular node or "involvement [Bewandtnis]" in what Matthew Ratcliffe helpfully calls a "teleological web." 3 So, as the familiar example has it, a hammer is used in order to pound nails, which activity is oriented towards the building of the house, and this is done for the sake of sheltering some Dasein or other. These concrete reference relations thus define how the hammer is involved with other entities, and so what a user must understand in order to treat it as a hammer. This invites the thought that specific

Problem der Metaphysik [hereafter KPM], included in the $5^{\text {th }}$ edition [Frankfurt am Main: Vittorio Klostermann, 1991]). It seeks to show he didn't fully get clear on something central to his own project, even as he made it possible for us do so, namely, how that very project is a possibility for the kind of entity described in it. But violence of this sort is, Heidegger thinks, philosophically charitable, even if it goes against more standard ideas of charity in interpretation. If my reading is sound, however, then it's the case that other readings that may be more charitable in the usual sense fail philosophically.

${ }^{1} S \& Z$ 6. "On the basis of which" isn't an ideal translation, but literal English equivalents are unworkably awkward. Like most of Heidegger's technical terms, we need to understand its meaning by way of its use within his philosophical system. See my "Heidegger on Understanding One's Own Being" (op. cit.) for a more developed picture of the theory of understanding I present here.

${ }^{2} S \& Z$ Div. I, Chs. II-IV.

${ }^{3}$ Matthew Ratcliffe, "Heidegger, Analytic Metaphysics, and the Being of Beings," Inquiry 45 (2002), 35-57, here 40. 
involvements are what Heidegger has in mind when he refers to that "on the basis of which" we understand things of use as the entities they are - so the hammer's being would just be its particular involvement or functional role in the web it is a part of. Heidegger's text would even seem to bear this out: "the being of the intra-worldly entity is involvement [Bewandtnis ist das Sein des innerweltlichen Seienden] [...] Simply as an [intra-worldly] entity does it have an involvement. This, that it has an involvement [...] is the ontological determination of the being of this entity [Sein dieses Seienden], not an ontical expression about that which is [das Seiende]."

But Heidegger is not here equating the being of an entity with its particular involvement in the particular teleological web it is part of. Careful attention to the articles he does and doesn't use here shows that he is instead making a constitutive claim about readiness-to-hand as a general way of being: what determines ready-to-hand entities ontologically is not their particular involvement but rather the fact that each has an involvement, whatever it might happen to be. Thus, each intraworldly item of equipment has exactly the same mode of being as every other: involvement, readinessto-hand. These label the most general category (in a suitably broad sense of the term) that allows us to grasp all particular items of equipment and particular teleological webs as items of equipment organized into webs. If we identify the being of a thing of use with its particular involvement, then that "on the basis of which" the entity is understood is no longer a general or formal structure, something that is understood in the case of any ready-tohand entity. And it is, of course, this formal structure that the relevant sections of $S \& Z$ are trying to get in view and articulate as the being of intraworldly entities.

Turning now to Dasein - the entity we each ourselves are - a parallel point about its being may be made. Just as it is tempting to identify the being of an intra-worldly entity with its particular involvement, so too is it tempting to identify my being as my particular place in the teleological webs I inhabit - roughly what contemporary philosophers such as Christine Korsgaard call my "practical identity." For it is natural to say that who I am is what I do: my roles, relationships, projects, etc. (which, of course, are that in relation to which intra-worldly things show up as the particular useful or useless things they are). ${ }^{2}$ My practical identity thus seems to be precisely that

\footnotetext{
${ }^{1} S \& Z 84$

${ }^{2}$ Versions of this thought are perhaps most clearly developed by Mark Okrent and William Blattner, though Ernst Tugendhat anticipates them in some ways. See Mark Okrent, Heidegger's Pragmatism (Ithaca: Cornell University Press, 1988), and
} 
on the basis of which I understand myself as being who I am. But, like involvements and teleological webs, practical identities are ontical and particular: they vary from person to person, place to place, and time to time. So, for instance, to say that I am a professor, or parent, or citizen (or a synthesis of all three and more besides), or even to follow Hamlet in asking whether I should be or not be at all, is to understand and deal with myself as a particular, determinate entity. What Heidegger officially identifies as the being of Dasein, however, the trifold, articulated structure he calls care (Sorge), ${ }^{1}$ doesn't vary in the way individual identities do. When I, as a philosopher, see and say that my being as Dasein is care, I conceptualize myself in terms of a general, universal, a priori form or way of being that also is instantiated in any other entity who understands entities as being.

Now, as with our understanding of tools etc. via the categories such as involvement that articulate the form of readiness-to-hand, we all have, according to Heidegger, a tacit understanding of our own form, and this understanding is necessary for being an entity with this form, even though we don't typically make this understanding explicit. ${ }^{2}$ But this means that, again as with the articulation of the being of the ready-to-hand, the ontologist seeks and sees something that others don't: the disclosure of a universal structure on the basis of which entities are intelligible in their particularity as the most basic kind of entities they are - in this case our own ontological structure as entities who find ourselves and other entities intelligible. ${ }^{3}$

"Heidegger and Korsgaard on Human Reflection," Philosophical Topics 27:2 (1999); William Blattner, Heidegger's Temporal Idealism (New York: Cambridge University Press, 1999); and the lectures on Heidegger in Ernst Tugendhat, Selbstbewusstsein Und Selbstbestimmung: Sprachanalytische Interpretationen (Frankfurt am Main: Suhrkamp Verlag, 1979) (English translation: Self-Consciousness and Self-Determination, trans. Paul Stern [Cambridge, MA: The MIT Press, 1986]).

1 Care is the structure of any entity who has "mineness [Jemeinigkeit]" and "existence [Existenz]" (its being at issue) as determining ontological features, and who is a self in a world with others. These initial "indications" of the being of Dasein give way to the articulated, triadic structure of care (which then opens up the parallel articulated, triadic structure of temporality) as Heidegger focuses on what is most essential to our being.

${ }^{2}$ I'm not defending this apriorism here, though I think it is defensible. For some attempt at a defense, see my "Heidegger on Understanding One's Own Being" (op. cit.).

${ }^{3}$ Part of Heidegger's picture is that ontological kinds are differentiated not simply by which properties define each, but by what it means for entities to "have" their properties. A thing "has" the property of being a hammer in a way that differs from how, say, a rock "has" the property of being a certain mass. One of Heidegger's 


\section{§3. Ontology and Breakdown}

So: how does this ontological "sight" of our own being occur? How do we move from a "pre-ontological" to an ontological understanding of ourselves? To answer this, let's again consider the ready-to-hand, for there are, as before, errors often made with respect to it that get carried over into the account of Dasein.

Note first that, related to the temptation to identify the being of a ready-to-hand entity with its particular involvement rather than with the general category <involvement>, is the temptation to see such general categories as disclosed in the breakdown or interruption of normal practical activity. ${ }^{1}$ As Hubert Drefyus says, articulating a widely held view, "the breakdown of a piece of equipment [Zeug] reveals the nature both of equipmentality and of the referential whole." But there is, in fact, no reason to think such revelation occurs in actual instances of breakdown. If, for instance, the head flies off the hammer a carpenter is using in the course of building a house, she may come to notice explicitly the various elements in the particular teleological web in which the hammer has its involvement: this broken hammer, these materials it was being used to work on, this house that these materials will compose, these buyers who will be upset by the delay, etc. But all of this is still ontical: what is noticed are other particular entities and the totality of particular referential relations among them. The mere presence of a totality that was previously not explicitly in view is insufficient to see what Dreyfus calls "the nature of ... equipmentality," i.e., the ontological categories <involvement $>$, < readiness-to-hand $>$, etc., that we talk about when we as philosophers describe what is characteristic of any and all things of use.

But doesn't Heidegger himself tell us that breakdown is ontologically revelatory? Yes, but not in the way usually thought. To understand what he is saying in the passages that talk about the disruption of our practical activity,

main criticisms of the philosophical tradition is that when it distinguishes ontological kinds, it nevertheless imposes a uniform logic on all of them, i.e., it treats all entities as substances with properties. His guiding insight, which I hope to work out in more systematic detail in the future, is that the meaning of "is" by which we articulate our understanding of entity-property connections varies, but has an underlying unity that is temporal in nature.

${ }^{1}$ See $S \& Z \S 16$ for the discussion of breakdown and the like which gives rise to the interpretation discussed.

${ }^{2}$ Being-in-the-World: A Commentary on Heidegger's Being and Time, Division I (MIT Press, 1990), 179; hereafter this will be cited as BITW. 
we do not need actually to be experiencing a hammer breaking, or any other particular experience like it. In fact, such an experience, if it occurred while reading and thinking, would disrupt our understanding, not enable it. What we must be doing is imagining the relevant sort of experience, giving to ourselves the matter which we are interested in - of which we then reflectively ask ontological questions. ${ }^{1}$ This is crucial: without imagining a particular sort of experience and then taking up that particular ontologicalinterrogative perspective deliberately, the being or "nature" (as Dreyfus calls it) of the ready-to-hand won't ever explicitly show up. And it's precisely that ontological-interrogative perspective that is missing from actual work situations in which things break down. ${ }^{2}$

Moving now to Dasein, many readers of Heidegger think we can (and that he does) explain the disclosure of Dasein's being through the experience of significant breakdown or trauma in one's life that is analogous to the experience of the hammer breaking. In this sort of experience one feels anxiety in the face of death (the possibility of not being at all); thus Dreyfus says (extending the quotation given above) that, "just as the breakdown of a piece of equipment reveals the nature both of equipmentality and of the referential whole, so anxiety serves as a breakdown that reveals the nature of Dasein and its world." 3 The idea is that in an anxiety-inducing rupture in the smooth functioning of one's life, the totality of meaningful relations within which one lives is lit up, along with one's singular place in it, just as the web of the hammer's relations is lit up when it breaks; and in this new vision of

\footnotetext{
${ }^{1}$ Heidegger does not present what he's doing via the concept of imagination, but, as I will suggest in my Conclusion, he came to see what he was doing as a kind of imaginative work when he turned to interpreting Kant. Cf. Jean-Paul Sartre's remarks on the role of imagination in Husserl's account of elucidating essences: "Phenomenology seeks to grasp essences. That is to say, it starts by placing itself from the outset on the terrain of the universal. Of course, it works well with examples. But it matters little that the individual fact that serves as a support for the essence is real or imaginary" (The Imagination, trans. Kenneth Williford and David Rudrauf, [New York: Routledge, 2012], 126).

${ }^{2}$ In high school and college, I worked in a bicycle shop that had too many mechanics for the number of tools there were, so we were constantly pilfering each other's and thus constantly experiencing our own as missing. This led to no deep ontological discussion, just frustration that the owner was too cheap to supply us all with what we needed to do our jobs.

${ }^{3}$ BITW, 177.
} 
oneself and one's world, one is forced to confront how (or whether) one will go on at all. ${ }^{1}$

Now, on the face of it, experiencing in real time such a situation of extreme breakdown in the meaningfulness of one's world doesn't seem like it would be conducive to the sort of patient, careful, time-consuming, deeply reflective work required of ontology, which, if anything, requires a stillness in one's life, which is completely at odds with the experience of massive breakdown. ${ }^{2}$ To think being in crisis is somehow essential to doing ontology implausibly turns it into (with apologies to poet Frank O'Hara) a kind of "meditation in an emergency." Relatedly, the unpredictability and variability of that which triggers breakdown is also at odds with philosophical work. Phenomenological ontology is, after all, a discipline, something one may work at, and so it requires one be able to pursue it, not just wait for the mood to strike. ${ }^{3}$

${ }^{1}$ Different readers spell out the details of this idea in different ways, but it is ubiquitous in the literature See, for instance, William Blattner, op. cit.; Iain Thompson, "Rethinking Levinas on Heidegger on Death," The Harvard Review of Philosophy, XVI, 2009, 13-43; Bruce W. Ballard, The Role of Mood in Heidegger's Ontology (Lanham, MD: University Press of America, 1991); Matthew Ratcliffe ("Heidegger's Attunement and the Neuropsychology of Emotion," Phenomenology and the Cognitive Sciences [Dordrecht: Kluwer Academic Publishers, 2002], 287312), and Robert Stolorow (World, Affectivity, Trauma: Heidegger and PostCartesian Psychoanalysis [Routledge, 2011]). John Haugeland has an interpretation that also develops this idea, but because he denies that "Dasein" denotes individual persons, his account differs in significant ways from these others. Still, the idea of breakdown as ontologically disclosive is central (Dasein Disclosed [Cambridge, MA: Harvard University Press, 2013]).

${ }^{2}$ There are, it's worth noting, comparably extreme positive experiences, ones in which everything lights up with meaning - joy at falling in love, at perceiving great beauty, in experiencing grace (if there be such a thing), etc. But these tend to be experiences in which we have the feeling of being moved, whereas trauma and affliction involve one's usual movement being brought to a screeching halt. The question trauma or breakdown poses is how to get going again once one life has been arrested. This forces a visibility of and confrontation with oneself that is much different than that in joy.

${ }^{3}$ Everything in the work Heidegger actually produces attests to this, as does the fact that his readers can profitably take up his work in the same sort of rigorous and deliberate way that he took up the work of other philosophers. Thus, when he says in "What is Metaphysics?" that the mood of anxiety in which we encounter "the nothing" resists our freedom, that "we are so finite that we cannot even bring ourselves originally before the nothing through our own decision and will," he 
Even supposing there are some who find they can do ontology even as everything is falling apart, it doesn't ultimately matter. For the sort of revelation of self and world in the midst of anxiety in the midst of breakdown isn't, in fact, ontological at all, in Heidegger's sense of that. What one is confronted by in breakdown is precisely not that which is formally shared by any and every Dasein. One is instead confronted - as forcefully as possible, to be sure - with precisely the opposite: one's own life and one's own practical identity and one's own world and one's own question of how (or whether) to be all. Crisis raises the question, "(how) shall $I$ go on living this life that is my own?" But the question of interest to the ontologist is: what makes any life a life at all?", or, "what is it to be the kind of being who can be faced by the question '(how) shall I go on living'?" or "what is 'myownness'?" Whatever the lived experience of trauma or breakdown does, it doesn't make explicit those general questions or what's needed to answer them, any more than experiencing a broken hammer by itself raises the question of what, in general, it is to be a thing of use.

Now, one might be willing to concede part of this and say that being in an experience of breakdown isn't required of the philosopher, while still wanting to insist that there remains a close connection between breakdown and ontology, namely, that the one who has experienced such breakdown had disclosed to her something that is essential if she is going to go on and try to articulate this structure. For hasn't she experienced in a way others haven't the singularity of her existence, the demand to take responsibility for it and determine it, and the wholeness of the world within which such responsibility must be taken - all things an adequate ontology of Dasein will need to have in view insofar as they represent instances of Dasein's general structure and possibilities? The one who has experienced directly her particular case of these general possibilities has, this thought would have it, taken a step towards ontology that someone lacking such an experience hasn't, even if she hasn't yet come to formulate what she has experienced in general ontological terms. ${ }^{1}$

cannot reasonably be understood to be talking about the mood required for doing ontology, which we can work ourselves into and return to more-or-less as needed (Wegmarken, GA 9, [Frankfurt am Main: Vittorio Klostermann, 1976] [English translation: Pathmarks, ed. William McNeill (Cambridge: Cambridge University Press, 1998)], 119/93); cf. $S \& Z$ 297). In this way, anxiety (as the mood of ontology) differs from other, less "pure" moods.

${ }^{1}$ Thanks to Clark Remington for this way of putting the point. 
While somewhat more plausible than the idea that being anxious in the midst of breakdown is essential for doing philosophy, I still think this is problematic. First, it implies that an experience of massive trauma or crisis is a pre-condition for being able to talk about and interpret the ideas in $S \& Z$, which means - taking the idea to its obviously absurd extreme - we ought to be demanding biographical testimonies to be appended to all scholarly work on the book so as to weed out as illegitimate all those readers who have had the misfortune of having led reasonably happy lives. Second, by making an experience of massive breakdown a pre-condition for doing ontology, little room is left for seeing quite different (and less disruptive) sorts of experiences as provoking ontological questioning - simple curiosity or wonder about what is, for instance. And third, insofar as it bumps anxiety back to a prior, pre-philosophical experience, it leaves as an open question what the mood is of the philosopher who is actually contemplating being by recollecting her prior anxiety.

There remains, however, an alternative to understanding the relation between crisis and ontology, a version of which I will develop and defend, which is suggested by the earlier considerations about the disclosure of the being of equipment. The idea is that, just as that disclosure depended on us reflecting on the breakdown of a teleological web, so too does the disclosure of the being of Dasein depend on reflecting upon the imagined experience of extreme breakdown. This sort of imaginative activity requires only that one have experienced some relatively small-scale disruption as the basis for extrapolation in thought to the more robust versions of disruption Heidegger refers to - and it's fair to assume all human beings have experienced such small-scale events, given our common finitude and fallibility.

I'll say more about this idea of imagining breakdown in the next section, where I argue that we can make good sense of $S \& Z$ if we see it as requiring such an imaginative performance of each of us, but let me wrap up this section by briefly considering a novel interpretation of anxiety recently offered by Katherine Withy. ${ }^{1}$ Withy's interpretation shares with the one I am developing here the focus on the methodological role in ontology that Heidegger gives to anxiety, which many commentators forget, and it stands out for explicitly rejecting the widely held idea I've been discussing, that Heidegger's anxiety should be understood as the mood of extreme breakdown. Distinguishing Heidegger's "Angst" from "anxiety" (and render-

\footnotetext{
1 "The Methodological Role of Angst in Being and Time," Journal for the British Society of Phenomenology 43:2, May 2012, 195-211.
} 
ing it into English as lowercase-a "angst") in order to keep the psychological connotations of "anxiety" at bay, Withy writes:

... Heidegger's angst is a rupture in a life. It is a crisis of the everyday. In the experience of angst, my ordinary life collapses - but not in the sense that it falls to pieces and I have to put it back together again. Rather, my life collapses away from me. ${ }^{1}$ Engagement in my daily tasks and concerns is suspended, and the day-to-day of life shrinks into insignificance. But unlike anxiety, angst has a positive valence. This breakdown is a legitimate revelation. Where I ordinarily see the myriad tasks ahead of me and the particular entities before me, in angst I see my life as a life, and the whole world as a world. Angst is an experience within a life that provides genuine ontological insight into what it takes to lead a life. ${ }^{2}$

In working this out, Withy makes good sense of the idea that there is a mood in which, in the course of our lives, we somehow see those lives as a whole without them having broken down as they do in trauma or crisis. The coherence of their meaning is maintained, but one nevertheless comes to feel distanced from them. And her position that Heidegger at least sometimes has this seeing in mind when he talks about Angst/anxiety, is convincing.

But the seeing of oneself and one's life that Withy describes is still, by Heidegger's lights, ontical, not ontological. For having my life as a whole in view is analogous to the carpenter having her whole teleological web in view, or the one in breakdown having her whole life in view as a question. What is in view is in each case, despite its putatively global character, still a particular something that is - an entity. By contrast, being is, as we have seen, universal and formal: it is that on the basis of which particulars are grasped as the kinds of particulars they are. Withy's reference to "what it takes to lead a life" comes close to capturing the formality of the ontological, insofar as it refers to $a$ life rather than $m y$ life, but in her account the emphasis still remains on what the ontological inquirer's own situation demands of her in order to carry on. As I argued above, however, the question of how $I$ go on is not the question of the ontologist carrying out the kind of investigation represented in the pages of $S \& Z$. Thus, despite the insights in Withy's interpretation, the main problems I identified with the breakdown-focused interpretations of it hold as well.

\footnotetext{
${ }^{1}$ The phrase "collapses away" appears in Dreyfus, op. cit., 179.

${ }^{2}$ Withy, op. cit., 196.
} 


\section{§4. Heidegger's Anxiety}

I've argued that standard ways of interpreting anxiety fail to show how it could be the mood required of the one who is actually doing ontology. I now turn to the text of $S \& Z$ in order to show how we can and need to read it as offering an account of anxiety as the mood of the philosopher.

Turning first to Ch. VI of $S \& Z$ Div. I, "Care as the Being of Dasein," we find the chapter beginning with "the question of the originary wholeness of Dasein's structural whole [ursprünglichen Ganzheit des Strukturganzen des Daseins]." The "structural whole" of Dasein referred to here is clearly the whole of Dasein's form, i.e., care (Sorge), that which constitutes any entity as Dasein and not something else. And the question is not just what this wholeness is, but also how it is possible to get it into view; ${ }^{2}$ it is the question of how Dasein can achieve the "access to itself [Zugang zu ihm selbst]" 3 that offering a thematic, ontological interpretation of itself requires. This means that we need to read whatever follows as focused not on any question about how (or whether) to live, but rather on this distinctly philosophical-methodological question of how it is possible to achieve a distinctly philosophical, i.e., universal, sort of understanding of oneself. And this is a matter of self-understanding: the "mineness [Jemeinigkeit]" of Dasein that has shaped the entire investigation up to this point is now front and center, and so the question about Dasein's totality is the question of how $I$ can bring my own structural totality into view.

In $\S 39$ Heidegger presents this question of ontological self-access as that of whether there is "in Dasein an understanding Befindlichkeit in which Dasein has been disclosed to itself in a distinctive way." ${ }^{4}$ More specifically, this is the question of whether there is a mood that provides a "way of disclosure in which Dasein brings itself before itself" such that "in it Dasein itself becomes accessible as simplified in a certain way." Heidegger's answer is yes, there is such a mood, one that can "provide the phenomenal basis for explicitly grasping Dasein's originary wholeness of being," 6 and

\footnotetext{
${ }^{1} S \& Z 180$.

${ }^{2} S \& Z 181$.

${ }^{3} S \& Z 182$.

4 “[E]ine verstehende Befindlichkeit im Dasein, in der es ihm selbst in ausgezeichneter Weise erschlossen ist" $S \& Z, 182$. This is one of those places where I think Heidegger ought to have referred to mood (concrete mode) rather than Befindlichkeit (category/existentiale).

${ }^{5} S \& Z 182$.

${ }^{6}$ Ibid.
} 
that the mood that "simplifies" Dasein in such a way as to allow ontological self-disclosure is anxiety. This bears emphasis: anxiety is introduced as the mood that someone, as ontologist, must be in in order to see herself "simplifed" in such a way that her own ontological structure rather than anything ontically particular becomes visible. Yet there's no suggestion that one must wait for one's life to actually break down (or "collapse away") in order to do philosophy, nor a presumption that one be in the middle of such a breakdown (or collapse), nor an insistence that one's life be in question in this simplified condition. So, at this stage at least, anxiety need not be interpreted as the mood of actual breakdown (or collapse), but rather as the mood of the ontologist engaged in the project underway in $S \& Z$. It is a mood in which I find myself not in terms of what defines me within the teleological webs I inhabit via my particular practical identity, but simply in terms of the fact of my existing in such webs (a world) at all as $a$ Dasein. This does, admittedly, make it odd to call the mood in question anxiety, which invites confusing emotional distress with philosophical insight. But nevertheless, if we focus on the philosophical project of the book and the question Heidegger himself raises about seeing Dasein's ontological form, its being, we can see that we need to put aside any tendency to think 'anxiety' refers to what we ordinarily take it to (a need Withy, to her credit, emphasizes as well).

Heidegger details anxiety in $\S 40$, drawing on his previous discussion of the mood of fear in $\$ 30$, which he uses to bring out the basic structure all moods share and then to provide a contrast with anxiety. In fear, we fear for our life or some aspect of it, and we are afraid "in the face of [wovor]" something in the world that threatens us (a bear chasing us, losing our job, etc.). Our fearing thus relates us to the world and entities in it in a particular, determinate way (as do most moods). Anxiety, by contrast, has no entity in the world - no thing or event - as its object, i.e., as that "in the face of which" one is anxious. Thus, in anxiety one finds oneself withdrawn from determinate relations to specific entities, and so "the world as such is that in the face of which one has anxiety." Now, if this simply meant one's own particular world, disclosed in its breakdown, we wouldn't have the relevant mood necessary for disclosing Dasein's - any and every Dasein's - being. But here "the world as such" refers not to the world conceived of as a totality of entities, nor as any particular world of an individual or group of individuals; rather, it is world as worldhood, what earlier in $S \& Z$ Heidegger had identified as the sense of "world" in which it is not taken ontically, as an entity, but rather ontologically, as the condition of possibility for my having

${ }^{1} S \& Z 187$. 
ontical possibilities in my particular world. ${ }^{1}$ This means, then, that "being-inthe-world itself is that in the face of which anxiety is anxious." "And this in turn means that that for which I am anxious is not myself, understood as this or that agent determined by a specific set of intra-worldly possibilities, but myself simply as the kind of entity for whom existing in the world is its way of being. It follows that that for which and that of which I am anxious are the same: my own being, formally understood as being-in-the-world. Keeping in view the question about philosophical access to formal ontological structure that led to this point, this means that anxiety is the mood in which we are attuned to ourselves in such a way that what is before us is our own form a form shared by any and every Dasein.

Now, Heidegger describes the self-relation involved in this as one in which "anxiety individualizes Dasein and thus discloses it as 'solus ipse.."3 So, while I am attuned to a form that characterizes every entity who is a Dasein, I only do so by seeing it as the form of first-person singularity, which I can only do by seeing it 'through' me: I both see myself as a self, and yet I see what Heidegger calls elsewhere "the essence of mineness and selfhood as such [das Wesen von Meinheit und Selbstheit überhaupt]." ${ }^{4} \mathrm{He}$ insists, however, that the "solipsism" here is not that of "putting an isolated subject-thing into the innocuous emptiness of a worldless occurring," for precisely what I see and describe is the fact that I - and any 'I' - exist in a world with others, even as I have withdrawn from the particular aspects of my own world and the others in it. Still, there is a clear echo of Descartes here, ${ }^{6}$ who, in raising skeptical questions, set the world aside so that, through

\footnotetext{
${ }^{1} S \& Z 64-5$.

${ }^{2} S \& Z 187$.

${ }^{3} S \& Z 188$.

${ }^{4}$ Metaphysische Anfangsgründe Der Logik Im Ausgang Von Leibniz (Frankfurt am Main: Vittorio Klostermann, 1978), 242; translated by Michael Heim as Metaphysical Foundations of Logic (Bloomington: Indiana University Press, 1984).

${ }^{5}$ Ibid. Heidegger's target here is, in part, Descartes, but in fairness to Descartes, it should be noted that he never eliminates world. The idea of material being is part of the stock of ideas in the meditator's mind, and it constantly poses a question to the meditator throughout the Meditations of how properly to understand it.

${ }^{6}$ Obviously there is an echo of Husserl as well, but I mention Descartes here and in my Conclusion because it allows something crucial about Heidegger's own method to easily be seen, and in order to sidestep the many thorny questions about Husserl and Heidegger's relation to him. Seeing a Cartesian antecedent to Heidegger's method that he himself acknowledge also provides an entry point for framing the
} 
a pure self-encounter, the grounds of intelligibility of all that is could come into view. And just as his uncertainty wasn't that of someone who really doubted the world - which, he thought, would be tantamount to insanity so Heidegger's anxiety isn't the mood of someone who is really experiencing the breakdown of all intelligibility. It is rather a deliberately induced analog to that mood.

So far, then, despite the fact that the term "anxiety" invites one to think of extreme psychological disturbance (occasioned in whatever way), we can see that in order to answer the question about ontological methodology that Heidegger himself raises, we can and must interpret anxiety differently. It is not a mood of disturbance; rather, it is a distinctly philosophical mood with no essential 'feel' to it, in which one finds literally nothing before her - no thing, no entity - but instead that which is not an entity, i.e., the form of her being as Dasein.

It may seem, however, that Div. II poses insuperable difficulties for this methodological interpretation of anxiety, for it seems pretty clearly to offer an "existentialist" account in which anxiety is the mood of extreme breakdown within (or collapsing away of) one's life. But observe that Division II begins by indicating a continuing concern with the methodological issue broached in Div. I, namely, that of how as philosophers we can get the whole of Dasein's ontological structure in view. Here Heidegger describes this as the task of "putting Dasein as a whole into our fore-having [Vorhabe],"1 the results of which, he says, will necessarily have a "peculiar formality and emptiness. ${ }^{2}$ This is because the wholeness that is sought is specifically not that of me as the particular person I am or the particular world within which I am normally situated. What Div. II seeks is, rather, a further discursive ontological characterization of the general nature or form of Dasein. Div. I had only looked at the formal whole of everyday, fallen, inauthentic Dasein. In Div. II we want also to see the form which includes the possibility of authenticity, i.e., of taking responsibility for one's existence (however that is to be understood). So, whatever else Heidegger is doing in

question of how properly to see the philosophical relation between Heidegger and Husserl, a task I will take up elsewhere.

${ }^{1} S \& Z$ 233. The term "fore-having" alludes to Heidegger's discussion of the "forestructure" of understanding, discussed in $\$ 32$ "Understanding and Interpretation." I leave aside details of this here, for they do not bear on my main argument.

${ }^{2} S \& Z 248$. 
the 'existentialist' passages of Div. II, he is somehow also giving us a story about what is required in order to do thematic ontology. ${ }^{1}$

The structural possibility of authenticity needs additional investigation because, Heidegger thinks, we tend to evade or cover it up: "Dasein's way of being [Seinsart] [...] demands that any ontological interpretation [Interpretation $]^{2}$ which sets itself the goal of exhibiting the phenomena in their originariness, should capture the being of this entity, in spite of this entity's own tendency" to hide (from) it. ${ }^{3}$ This raises the question about how ontology is to "get the evidence" 4 it requires in order to insure that what it says about Dasein's being is true and adequate. How, in other words, can we as philosophers articulate what authenticity is as a basic possibility of Dasein? As in Div. I, Heidegger's answer to the question of how ontological self-disclosure occurs hinges on anxiety. The "Grundbefindlichkeit" of anxiety, ${ }^{5}$ Heidegger says, is "the most elemental way in which thrown Dasein is disclosed," and, as such, "it puts Dasein's being-in-the-world faceto-face with the 'nothing' of the world; in the face of this 'nothing,' Dasein is anxious with anxiety about its ownmost ability-to-be [Seinkönnen]." Echoing this, in his discussion of death, understood by Heidegger as "the "possible impossibility of existence," ${ }^{, 7}$ he claims that "being-towards-death is essentially anxiety." "This possibility is "attested" to in "conscience," which Heidegger understands as a kind of discourse in which one "calls" to oneself, though in an odd sort of way, for in it nothing is said, and the call seems to

\footnotetext{
${ }^{1}$ If the possibility of authenticity were simply equivalent to the possibility of doing ontology, then the account of authenticity would be an account of what is required of the philosopher. I'll say more about why I think there isn't such an equivalence in my conclusion, but note that the earlier reflection on the distinction between the sort of question one faces in 'existential' crisis and the sort of question asked by the ontologist already implies that there is a distinction between the achievement of the philosopher and the one who acts to go on in some way despite the crisis or breakdown she experiences.

${ }^{2}$ That is, not Auslegung, but rather the specific form it takes in the thematizing activity characteristic of philosophy. Heidegger is not always consistent, but he generally uses the Latinate term to identify the specifically philosophical form of interpretation.

${ }^{3} S \& Z 311$.

${ }^{4} S \& Z 312$.

${ }^{5}$ Again, were Heidegger entirely consistent in his terminology, this should be ground-mood (Grundstimmung), not Grundbefindlichkeit.

${ }^{6} S \& Z 276$.

${ }^{7} S \& Z 265$.

${ }^{8} S \& Z 266$.
} 
be both mine and not mine - "from me and yet from beyond and over me."1 This call, nevertheless, brings me into anxiety so that I realize that I am "guilty [schuldig]," ${ }^{2}$ which means both thrown into and yet responsible for my own existence. From this position, I can then accept or refuse the responsibility for myself that is disclosed to me: I can be "resolute" and so authentic, or not.

All of this can undeniably be read - particularly if we forget the methodological question leading up to it - as an "existentialist" description of self-confrontation, i.e., one in which I find myself dealing with the whole weight of my presence in the world and the responsibility I have for it, and so confronted with the possibility of resolute authenticity or its refusal. But if we leave things there, then we haven't addressed the methodological question Heidegger begins with, that of how we as philosophers are able to 'see' and conceptualize these formal aspects of Dasein's being. Heidegger, however, is clear: we need not only say what Dasein's being is; we need to be able to say how we can say it. Here, briefly, is how we can see these "existentialist" passages as doing just that.

First, the question about what Dasein as such is requires that we each, as inquirers, set aside what differentiates us from others in order to focus on what constitutes us as the same. And, because of the essential "mineness" of Dasein, its first-person singularity, this question requires that I (as inquirer) pose the question not only of but also to myself (likewise with you to yourself). But asking a question is a discursive action, with both a speaker and a hearer. In the case of this ontological question of the "sum" (as Heidegger calls it in §9), speaker and hearer coincide; it thus represents me "calling" to myself. Because of the formality of the question, however, I call to myself not as me, this particular individual defined by this or that practical identity. Rather, I ask the question from "beyond" myself, that is, from outside of the perspective of my determinate identity as that is defined in relation to other determinate entities. Ontological self-questioning is thus a discursive activity which fits precisely the description of the mode of discourse Heidegger identifies with the call of conscience.

Moreover, in doing something (asking a question of myself), I also thereby affect myself (I "hear" the question), which entails an affective response on my part: I feel my action of questioning myself. This feeling that results from affecting myself by asking ontological questions of myself, the entity I am seeking to understand, is, then, the mood of philosophy, the

${ }^{1} S \& Z 275$.

${ }^{2} S \& Z 281$. 
Grundbefindlichkeit or ground-mood in which my being, my formal ground, becomes available for discursive analysis as other entities and my own determinate features cease to be present to me. ${ }^{1}$

Additionally, this mood is one in which, having withdrawn from all that is in order to get in view the basis of my understanding of that which is, entities (the world and my world-indexed determinations) may be said to have become "nothing." I have deliberately induced the philosophical mood I am in and so, in that sense, cultivated my "death," i.e., the "nothing" of that which is, entities. ${ }^{2}$

Lastly, to maintain myself in the position where I am able to do this requires a resolute commitment, i.e., a concerted effort on my part to maintain my withdrawal from entities so that I may focus on that on the basis of which they are intelligible. This isn't a commitment to living my life in any particular way, or even to taking seriously the demand on me to take up the question of how I ought to live my life. It is a commitment only to philosophical understanding, to keeping my focus on being rather than on those entities whose draw continually induces me to "fall" into the world.

With that we can see, at least schematically, how it is possible to read the "existentialist" discourse of Div. II in a way that shows it is about the issue of achieving the peculiar sort of ontological self-relation necessary for doing philosophy, rather than only about the confrontation with one's particular self in the midst of one's world. Anxiety is, within this, the mood of ontological self-affection.

\footnotetext{
${ }^{1}$ Because this is an ongoing process of actively doing something, it ultimately will allow us to find accessible our own temporal form as we instantiate it. Not incidentally, what we find available of ourselves will involve a hearing or seeing that doesn't involve an interruption, the "stilling of the stream" and subsequent construction that Paul Natorp thought all phenomenology must involve.

${ }^{2}$ Hannah Arendt, in her dissertation on Augustine, cites Plotinus, Enneads 6.8.4, 6.8.2 on the idea of spiritual self-relation as death (Love in Saint Augustine, Joanna Vecchiarelli Scott and Judith Chelius Stark, eds. [Chicago: University of Chicago Press, 1996], 21). I am suggesting that Heidegger (who would have, of course, known both the Plotinus and Arendt's discussion of it) is giving an analog of such spiritual self-relation, and that he sees it as the essential condition of doing ontology. This is but one case in which Heidegger appropriates the neo-Platonic elements of Augustine, discarding his Christian interpretation of them, but without simply reverting to earlier pagan formulations.
} 


\section{§5. Ontology and Life}

But what about the fact that Heidegger really does seem to be describing not just philosophical activity but lived 'existential' crisis? Is he conflating the mood of crisis and the mood of ontology? To some extent, I think, the answer must be yes, and I think there are probably deep-rooted psychological reasons he was inclined to do so. But we can, nevertheless, sort things out in a way which preserves both an ontological-methodological story about anxiety and an "existential" one in a way that is truer to the deepest aspects of his thought than he himself sometimes was. If we think back to the way in which imagining - as opposed to actually experiencing - a case of breakdown in the use of tools provided the basis for bringing the being of equipment into view, we can see something analogous with Dasein: imagining the extreme breakdown of our ontical existence can help us see all of (and only) our ontological form, for in imagining this breakdown we bring explicitly into view the bounds of what we are, that beyond which we are not. (Here again the parallel with Descartes noted earlier is illuminating; I'll touch on it again in my conclusion.) But we do so in such a way that we can conceptualize and describe it, rather than be confronted by it as the immediate issue of our individual lives. So we at once imagine a mood that would accompany actual breakdown, and, insofar as this imaginative activity is a self-affective one (we give to ourselves that which we consider in thought), we effect in ourselves an analogous mood in which we see such the essential possibility of such breakdown, along with the kinds of possible response to it that characterize any and every Dasein.

The fact that we deliberately imagine rather than live the experience of actual extreme breakdown, means that we as philosophers are insulated from the actual question "(how) do I go on?" that such breakdown would pose to us. Our question is instead, "what is it to be the kind of being who can ask itself '(how) do I go on?" It is, of course, tempting to think there is some deep connection between the self-understanding ontology provides and the demands of our actual lives. Heidegger himself talks about the activity of philosophy as constituting the "highest freedom,"1 undeniably inviting the thought that ontology illuminates, or in some way fully realizes, the lived existence of the particular person who does ontology. Nevertheless, when he is clear about this, he understands that the activity of ontology manifests a freedom from the demands of life. Ontology is an activity that is so free that

\footnotetext{
${ }^{1}$ See, for instance, Martin Heidegger, Phänomenologische Interpretation von Kants Kritik der reinen Vernunft [GA 25] (Frankfurt am Main: Klostermann, 1995), 27.
} 
we are free to take it up or not. The fact that we have such a possibility, a kind of activity that is of no necessity whatsoever, is what makes us what we are, thus engaging in it represents a kind of fulfillment of our being. But this is a fulfillment that is not connected to any other. If we think otherwise, that we must do ontology because it will answer some need outside itself, we are prone to confuse - with potentially disastrous results, as Heidegger's own life attests to - what Cora Diamond nicely distinguishes as "the difficulty of reality" and "the difficulty of philosophy." "In doing ontology I don't learn anything about how to live, certainly how to live my life. I only learn formal or structural possibilities I have as someone who has $a$ life. And so what I learn of life in general need place no direct demand on mine, nor respond to a demand in it. ${ }^{2}$ That, however, is not a mark against ontology. It is merely a recognition that, whatever importance it has, it is of an exceedingly strange and utterly impractical kind.

\section{§6. Conclusion}

I conclude by bringing out two connections my interpretation allows us to see between Heidegger and earlier figures and themes in modern thought. This will, I hope, help make what I have been saying seem a little less odd

1 "The Difficulty of Reality and the Difficulty of Philosophy," Partial Answers: Journal of Literature and the History of Ideas 1(2): 2003, 1-26.

${ }^{2}$ In this way, it is worth noting, Heidegger's ontological project differs from most of the great metaphysical projects of the modern period, where the task of seeking knowledge of soul, God, and world was undertaken in order that we would learn (each for ourselves) how to live rationally by eliminating the confusions we are too often prone to. These projects thus also respond to the afflicted state of humanity, but they do so because they begin with normative questions which Heidegger has eliminated. Heidegger's project also seeks the form of our own agency, but no norms for how to exercise it are derived, because none are sought. Only if we reintroduce the Platonic idea (partially retained by so many of the moderns) that being as such is good - so what is and what ought to be are in some way intrinsically connected could we expect discursive ontological understanding to be in some way linked to self-transformation. (But even then we would do well to heed Descartes advice to engage in metaphysics "semel in vita" — just once in one's life — and spend the rest of the time seeking empirical knowledge and learning to live well.) Heidegger's analyses, however, aim at a formal level which is "beyond good and evil." They presume that there is no a priori reason to think that what is and what is good are the same. There is no beatific vision of being, as Heidegger understands being. There is only pure self-perception, divorced from desire for the good. 
and thereby more compelling. First, as I hinted at earlier, the picture I have given of Heidegger portrays him as developing further Descartes' transformation of earlier neo-Platonism, according to which a method of selfengagement is needed in which the world is put in abeyance in order that we may see those universal structures or forms that ground the intelligibility of things in the world, which ground we are constantly "falling" away from as we live immersed in the world with others. Like Descartes, and in some ways Augustine, Heidegger thinks that the first form or ground of being we need to get clear on is our own, for built into it are the forms of all other entities that we understand - thus his hope of getting clear on our understanding of time as the deepest ground of our self-intelligibility and that of other entities as well. ${ }^{1}$ And, as I have been arguing, this requires cultivating a mood not unlike that of hyperbolic uncertainty that we find in Descartes.

Drawing Heidegger and Descartes together like this will no doubt strike many readers as implausible, but it is far less of a stretch than it might seem. In his lectures on Descartes given a few years prior to $S \& Z{ }^{2}$ Heidegger described Descartes' method of doubt (using what came to be important proprietary terminology) as one that leads me, the meditator, into an "end-situation" in which "my searching" is "placed before the nothing [das Nichts] and into the nothing." 3 And he said that the "nothing" here is to be understood as a negation "of the possibilities of still encountering something [der Möglichkeiten, noch etwas anzutreffen]." While no thing, no etwas, is encountered in this end-situation, this "nothing" into which I am brought isn't entirely lacking in content, for, Heidegger says, I still encounter my "being-searching [Suchendsein] [...] in its being [Sein]." For Descartes, my "being-searching" is the activity of asking questions about knowledge and being; as I explicitly come across my own active existence in the form it takes in this philosophical questioning, I recognize that, because this activity of questioning is mine, it "must be expressed by the 'sum'." The essential methodological move in Descartes, as seen from Heidegger's perspective is thus to withdraw from the world in such a way as to find a standpoint in

\footnotetext{
${ }^{1} S \& Z 13$.

2 I treat Heidegger's reading of this method at length in 'Heidegger's Descartes and Heidegger's Cartesianism" (op. cit.). There are obvious connections to Husserl here, but I think it is important to see the relation to Descartes (and Kant) on its own in order to then be able to appreciate how Husserlian Heidegger is, despite his attempts to distance himself from Husserl.

${ }^{3} E P F$ 239-40.

${ }^{4} E P F 240$.

${ }^{5}$ Ibid.
} 
which nothing, i.e., no thing, no entity, is present, for this will be at the same time the standpoint from which one's own being comes into view, and, through that, the fundamental basis of the intelligibility of other entities as well. Heidegger, of course, aims to carry out his investigation in a way that corrects for certain errors he saw in Descartes, corrections which would then allow the being of the "I" (expressed in "sum") to be interpreted as other than that of a particular kind of substance with properties. But to get to the "sum" he needs a method that parallels Descartes', and that's what he gives us.

The second connection I want to bring out builds on this first one. Heidegger came to be intensely interested in Kant's theoretical philosophy in the years immediately after $S \& Z$, finding in it an unprecedented focus on the idea that being is (as Platonic-rationalist philosophy had recognized) the universal and a priori ground of intelligibility of entities, and yet (in opposition to traditional Platonism and rationalism) not external to the knower: it is, rather, given by the knower to herself as the basis for her taking up concrete, empirical entities. To articulate or disclose ontological understanding - synthetic a priori knowledge, in Kant's terms - requires finding a way for the knower to make visible to herself, thus give explicitly to herself, that which she normally gives to herself only tacitly in her encounters with empirical objects. Heidegger sees Kant's account of pure imagination as precisely an account of this self-giving of ontological knowledge: ${ }^{1}$ we give ourselves the representations of our forms of intuition and of the modes of spontaneous combinatorial activity (categories), and we explicitly synthesize them into the principles that determine what nature as such is, prior to any articulation of its empirical laws.

My argument here has been that, prior to his serious investigation of Kant, Heidegger had already arrived at the idea that articulating the usually only tacit knowledge of being, the ground of intelligibility of entities, requires an act of pure self-giving in which we affect ourselves through ontological self-questioning so as to attune ourselves to our being, rather than the entities we ordinarily exist amidst. What Heidegger calls "anxiety" in $S \& Z$, insofar as it is the mood of the one working out the formal structure of Dasein, is precisely such a mode of pure self-affection. In it we are able to represent to ourselves what are ordinarily only tacit ontological forms that, like synthetic a priori knowledge with respect to the realm of nature, we give to ourselves as the ground of our ontical understanding. In light of the understanding of pure self-affectivity Heidegger develops in his work on Kant, calling the mood of the ontologist 'anxiety' looks like an unfortunate

${ }^{1}$ See Part Three of $K P M$. 
and confusing move. But sorting out the confusion reveals a compelling philosophical story about how it is that we come to see and say what we, as Dasein, are. ${ }^{1}$

\footnotetext{
${ }^{1}$ Thanks for discussion of earlier drafts of this paper (going back now a number of years) to audiences at the History of Philosophy Roundtable at UC, San Diego; the Southwest Seminar in Continental Philosophy at the University of New Mexico; and the International Society for Phenomenological Studies, in Kennebunkport, ME; and to various individuals, most especially Clark Remington and Katherine Withy.
}

27

Bull. anal. phén. XII 1, 2016

http://popups.ulg.ac.be/1782-2041/ @ 2016 ULg BAP 